\title{
Inflammatory arthritis or osteoarthritis of the knee - Efficacy of intra-joint infiltration of methylprednisolone acetate versus triamcinolone acetonide or triamcinolone hexacetonide
}

\author{
Artrite inflamatória OU OSTEOARTRITE dE JOELHO - EFicÁcia dA INFILTRAÇÃo \\ INTRA-ARTICULAR DE ACETATO DE METILPREDNISOLONA VERSUS TRIANCINOLONA ACETONIDA \\ OU TRIANCINOLONA HEXACETONIDA
}

Authorship: Brazilian Medical Association (AMB)

Participants: Antonio Silvinato ${ }^{1}$, Wanderley Marques Bernardo ${ }^{1}$

Final draft: June 27, 2017

${ }^{1}$ Associação Médica Brasileira (AMB)

The Guidelines Project, an initiative of the Brazilian Medical Association, aims to combine information from the medical field in order to standardize procedures to assist the reasoning and decision-making of doctors.

The information provided through this project must be assessed and criticized by the physician responsible for the conduct that will be adopted, depending on the conditions and the clinical status of each patient.

\section{GRADES OF RECOMMENDATION AND LEVELS OF EVIDENCE}

- A: Experimental or observational studies of higher consistency.

- B: Experimental or observational studies of lower consistency.

- C: Cases reports (non-controlled studies).

- D: Opinion without critical evaluation, based on consensus, physiological studies or animal models.

\section{ОвJective}

The objective of this evaluation is to provide, based on primary studies, the best current evidence on the efficacy and safety of intra-articular infiltration of methylprednisolone acetate, triamcinolone acetonide and triamcinolone hexacetonide in the treatment of inflammatory arthritis and osteoarthritis of the knee.

\section{DESCRIPTION OF EVIDENCE COLLECTION METHOD}

This guideline followed the standard of a systematic review with evidence retrieval based on the EBM (evidence-based medicine), so that clinical experience is integrated with the ability to critically analyze and apply scientific information rationally, thus improving the quality of medical care.

We used the structured mode of formulating questions synthesized by the acronym PICO, where P stands for adult patients with knee inflammatory arthritis or osteoarthritis,
I stands for single infiltration with methylprednisolone acetate, $\mathrm{C}$ refers to comparison with triamcinolone acetonide or triamcinolone hexacetonide, and O stands for outcome (pain, function, and adverse events).

Based on the structured question, we identified the descriptors that formed the basis of the search for evidence in the databases: Medline-Pubmed. Thus, 20 studies were selected by title and five were chosen, after eligibility criteria evaluation (inclusion and exclusion), for answering the clinical questions (Annex I).

\section{Clinical question}

What is the efficacy and harm of methylprednisolone acetate compared to triamcinolone acetonide or triamcinolone hexacetonide in the treatment of inflammatory arthritis and osteoarthritis of the knee?

\section{INTRODUCTION}

Several studies have suggested good efficacy and safety of intra-articular (IA) injections of corticosteroids (CS) among children and adults to treat diseases such as inflammatory arthritis, osteoarthritis (OA), rotator cuff syndrome, epicondylitis, and carpal tunnel syndrome. ${ }^{1-3}$

Osteoarthritis is the most common chronic joint disease in the world. ${ }^{4}$ It is a degenerative disease that affects joint cartilage leading to joint pain, stiffness, swelling and dysfunction. It has a multifactorial etiology (age, 
obesity, trauma, poor alignment and genetics). ${ }^{5}$ The joint most commonly affected by osteoarthritis is the knee, and the literature shows that more than $10 \%$ of men and more than $13 \%$ of women suffer from this degenerative disease. ${ }^{6}$ Intra-articular steroids are a good alternative for patients with osteoarthritis.

Rheumatoid arthritis (RA) is a chronic inflammatory disease that mainly involves diarthrodial joints. Intraarticular injections of glucocorticoid (GC) have been used for more than half a century in the treatment of refractory synovitis in RA patients. There are limited data on the effectiveness of intra-articular injection of various preparations of GCs in inflamed joints. ${ }^{7}$

\section{Selected eVidence Results}

Two randomized clinical trials (RCTs) $)^{8,9}(\mathbf{B})$ assessed the use of methylprednisolone acetate (MA) in patients with rheumatoid arthritis, comparing it with triamcinolone acetonide (TA) and triamcinolone hexacetonide (TH).

The first ${ }^{8}(\mathbf{B})$ randomized 100 patients aged between 18 and 65 years with rheumatoid arthritis $(n=89)$ or spondyloarthrosis $(\mathrm{n}=11)$, and who had a significantly swollen knee joint (defined as duration $\geq 1$ week and $<24$ weeks). Those who had received steroid infiltration in the same joint within the last three months were excluded. Additional use of intramuscular or IA (other joint) corticosteroid, or step-up therapy with oral steroids (prednisolone $\geq 7.5 \mathrm{mg} /$ day) was not allowed for four weeks. No local or diluted anesthetic was added to the corticosteroid agent. Patients received a single infiltration with MA or TA $(80 \mathrm{mg}$, $2 \mathrm{~mL}$ for both). Follow-ups were at 4, 12, and 24 weeks or whenever relapse (pain or swelling return to a condition similar to or greater than the baseline visit for week $\geq 1$ ) was suspected. Patients rated pain and swelling at the target joint using a numerical rating scale (NRS) ranging from 0 to 10 . The primary end point was flare time at 24 weeks, while secondary outcomes were change in pain and swelling reported by the patient at 4,12 and 24 weeks, range of motion at 24 weeks, and adverse events. There was no difference between the groups in relation to the number of patients who relapsed within 24 weeks $(\mathrm{ARR}=0 \%, 95 \mathrm{CI} 0.15-0.15, \mathrm{NNH}=\mathrm{NS})$. The mean time to relapse was not significantly different between the MA and TA groups (20.8 [95CI 18.8-22.7] weeks and 20.9 [95CI 19.0-22.8] weeks, respectively: $\mathrm{p}=0.9$, hazard ratio $=1.0$ [95CI 0.4-2.5]). In both groups, there was a significant reduction in pain and swelling at all visits compared to baseline ( $\mathrm{p}=0.001$, for all comparisons). Nevertheless, there were no significant intergroup differences (MA vs. TA) at 4,12 and 24 weeks ( $p>0.05$ for all comparisons). In the
ITT analysis, at 24 weeks, the results (mean \pm SD) for pain and swelling (MA vs. TA) were 2.5 (2.3) vs. 3.4 (3.1), $\mathrm{p}=0.33$, and $2.4(2.8)$ vs. $2.9(3.0), \mathrm{p}=0.16$, respectively. There was an improvement in the number of patients with normal knee flexion in both groups, but no difference between them in up to 24 weeks $(\mathrm{NNT}=\mathrm{NS})$. None of the patients had vasovagal syncope, hematoma, infection or hypopigmentation. Therefore, no significant differences in efficacy were found between knee infiltrations with MA and TA in patients with chronic inflammatory arthritis over a 24-week period. ${ }^{8}$ (B)

Another $\mathrm{RCT}^{9}$ randomized 30 adult patients, in either outpatient or inpatient setting, with rheumatoid arthritis showing classic presentation or according to the American Rheumatism Association criteria, and with both knees symmetrically affected by the disease, into three groups with a single infiltration of: MA (40 $\mathrm{mg}$ in $1 \mathrm{~mL} ; \mathrm{n}=10)$, TH (20 $\mathrm{mg}$ in $1 \mathrm{~mL} ; \mathrm{n}=10)$ and prednisolone t-butyl acetate (20 mg in $1 \mathrm{~mL} ; \mathrm{n}=10)$. Patients treated with IA or systemic steroids three months prior to the beginning of the study were excluded. Drug therapy remained constant throughout the study. Patients were followed up for six weeks and the outcomes evaluated were pain measured by visual analogue scale (VAS), duration of morning stiffness, grip strength, Ritchie articular index and thermographic index. The improvement in mean pain score was higher with TH than with MA at week $1(\mathrm{p}<0.05)$, but this difference was not significant at two weeks, suggesting a faster onset of action with TH compared with MA. Overall efficacy was similar, with no improvement in joint index, morning stiffness or grip strength using any of the corticosteroids compared to the baseline visit ( $p>0.5$ for all comparisons) within six weeks. ${ }^{9}$ (B)

Three RCTs assessed the use of MA in patients with osteoarthritis, comparing it to TH or TA.

The first triple blind ECR included 100 patients on an intention-to-treat analysis with knee OA, grade II and III Kellgren-Lawrence radiological classification, VAS for knee pain $\geq 40 \mathrm{~mm}$ (maximum $100 \mathrm{~mm}$ ), age $\geq 40$ years, and failure to control symptoms with prior or current analgesic drugs and/or NSAIDs. Patients with corticosteroid or hyaluronic acid infiltration in the six months prior to the beginning of the study, using anticoagulants, and those with BMI $\geq 35 \mathrm{~kg} / \mathrm{m}^{2}$ were excluded. Patients who were severely ill were also excluded, while adjustments were made for analgesia, NSAIDs and chondroprotective agents. No new pharmacological or non-pharmacological therapy for knee OA was allowed during the study. Patients were randomized into two groups (50 in each), and were treated with a single injection of: THA 
(40 mg [2 mL, $20 \mathrm{mg} / \mathrm{mL}])$ and MA (40 mg [1 mL, $40 \mathrm{mg} /$ $\mathrm{mL}$, plus $1 \mathrm{~mL}$ of lidocaine to yield equivalent injection volumes]). Follow-up time was 24 weeks, with visits at 4 , 12 , and 24 weeks. Patient's pain assessment on VAS (0$100 \mathrm{~mm}$ ) at week 4 was considered the primary endpoint, while patient's pain assessment at weeks 12 and 24 was one of the secondary outcomes. The other secondary outcomes were: global assessment of the disease by the patient (VAS), global assessment of the disease by the physician (VAS), global evaluation of the disease by the patient (Likert scale), the OA WOMAC (Western Ontario and McMaster Universities Osteoarthritis) questionnaire, the Lequesne algofunctional index, the OMERACTOARSI (Outcome Measures in Rheumatology Clinical Trials and Osteoarthritis Research Society International) criteria for significant improvement and adverse events; all were evaluated at weeks 4, 12, and 24. Both groups showed significant benefits for pain (VAS) in four weeks, which was maintained to a lesser extent in 24 weeks. There was also sustained improvement in measures related to the secondary outcomes, including the WOMAC score (a composite measure of activity-related pain, function, and stiffness). However, there was no significant difference $($ mean \pm SD) between MA $(48.1 \pm 28.7)$ and TH $(46.4 \pm 31.8)$ in pain assessment on VAS at week $4(\mathrm{p}=0.352)$, as well as at the 12- and 24-week follow-up visits. None of the secondary outcomes assessed at 4,12, and 24 weeks showed a statistically significant difference between MA and TH ( $p>0.05$ for all comparisons). There was one adverse event in the MA group (post-infiltration arthritis [pain, swelling, redness and joint effusion]) the day after the procedure, and none in the TH group. This study provided strong evidence that IA injections of TH and MA are equally effective in reducing pain and improving function in patients with knee OA who were unable to control symptoms with analgesics or NSAIDs. ${ }^{10}(\mathbf{B})$

Another RCT randomized 120 patients (55-75 years) with complaints of knee pain who met the American College of Rheumatology (ACR) clinical criteria for knee osteoarthritis with pain severity $\leq 5$ on VAS $(0-10 \mathrm{~cm})$, and grade $\geq 2$ on the radiological classification scale of Kellgren and Lawrence (moderate to severe disease [grade IV]). Patients who received intra-articular steroid in the last three months were excluded. This 12-week (30-patient in each group) placebo-controlled (IA saline $[\mathrm{NaCl} 0.09 \%$, $1 \mathrm{~mL}]$ ) study compared a single injection of three different corticosteroids (MA $40 \mathrm{mg}$ [1 mL], TA $40 \mathrm{mg}$ [1 mL] and betamethasone disodium phosphate $3 \mathrm{mg}[1 \mathrm{~mL}]$ ). The outcomes analyzed for up to 12 weeks were: visual analog scale pain (0-10 cm [VAS]), function according to the
Lequesne index (LI) and adverse events. The three corticosteroids promoted symptomatic and functional improvement for up to 12 weeks; however, MA was more effective in relieving pain compared with the other agents (TA, betamethasone disodium phosphate and saline) until week 6; $\mathrm{p}<0.05$ for all comparisons. There was no statistically significant difference between the MA and TA groups regarding the improvement in functional status (LI) up to 12 weeks (analysis at weeks 1, 3, 6 and 12). No local or systemic complications associated with infiltrations were observed. ${ }^{11}(\mathbf{B})$

A third RCT included 57 patients (mean age 62.5 years) with knee OA and joint effusion, who met the ACR criteria (clinical and radiographic) for knee OA presenting at least grade II radiographic OA changes according to the Kellgren-Lawrence classification system. Patients treated with infiltration in the last three months were excluded, as were those with severe OA (complete obliteration of joint space on the X-ray). Patients were randomized to receive a single IA injection of MA $40 \mathrm{mg}$, $1 \mathrm{~mL}(\mathrm{n}=28)$ or TH $20 \mathrm{mg}, 1 \mathrm{~mL}(\mathrm{n}=29)$. The follow-up time was 8 weeks ( 0,3 and 8 week analysis) and the outcomes assessed were pain intensity on VAS $(0-100 \mathrm{~mm})$, functional status according to Lequesne's index (LI), and time for ascending and descending stairs (TADS) using handrails. There was a significant improvement in pain with IA injection of MA and TH compared to the baseline visit; however, TH was more effective than MA in pain reduction (VAS) at week $3(32.9 \mathrm{~mm}, 95 \mathrm{CI} 23.4-42.4 \mathrm{~mm}$ vs. $13.7 \mathrm{~mm}, 95 \mathrm{CI} 2.8-24.8 \mathrm{~mm}, \mathrm{p}<0.01)$. This suggests a faster onset of pain relief with TH compared to MA. Only MA maintained this significant benefit (pain reduction) at week 8 compared to the baseline visit $(\mathrm{p}<0.05)$, but there was no difference between TH and MA at this follow-up ( $\mathrm{p}=0.17$ ). Compared with the baseline, both IA corticosteroids significantly improved the Lequesne index (LI) at week 3, but only MA maintained a significant benefit at week $8(p<0.05)$. However, there was no significant difference between the two drugs in the assessment of function (LI and TADS) at 3 and 8 weeks ( $>0.05$ for all comparisons). ${ }^{12}$ (B)

\section{Discussion}

Small number of good quality RCTs evaluating the efficacy of intra-articular infiltration of corticosteroids in rheumatoid arthritis or knee osteoarthritis, small sample in most studies, variable methodological quality, heterogeneity of outcome measures, different and short follow-up times, and doses of corticosteroids are factors that make it difficult to establish firm conclusions to guide treatment. 


\section{ReCOMmendation}

- MA and TA are equally effective in knee infiltration for the treatment of rheumatoid arthritis. (GRADE 1A)

- Infiltration with MA is more effective in relieving pain than TA in patients with knee OA in a maximum of six weeks, and equally effective in the improvement of function in up to 12 weeks. (GRADE 1B)

- The use of TH may be favored over MA for knee arthritis (RA or OA; 1 and 3 week analysis, respectively) based on the fastest onset of action for pain relief. (GRADE 1B)

- There is no difference between infiltration with MA and $\mathrm{TH}$ in pain relief for knee RA between 2 and 6 weeks. (GRADE 1B)

- There is no difference between infiltration with MA and $\mathrm{TH}$ in pain relief for knee OA between 4 and 24 weeks. (GRADE 1A)

- There is no difference between knee infiltration with MA and TH when functional improvement is evaluated, up to 6 weeks, in patients with RA. (GRADE 1B)

- There is no difference between knee infiltration with MA and TH when functional improvement is evaluated, up to 24 weeks, in patients with OA. (GRADE 1A)

GRADE 1A: strong recommendation, high-quality evidence; GRADE 1B: strong recommendation, moderate-quality evidence.

\section{Conflict of interest}

The authors declare no conflict of interest.

\section{References}

1. Bellamy N, Campbell J, Robinson V, Gee T, Bourne R, Wells G. Intraarticular corticosteroid for treatment of osteoarthritis of the knee. Cochrane Database Syst Rev. 2006; (2):CD005328. Review. Update in: Cochrane Database Syst Rev. 2015; (10):CD005328.

2. Gaujoux-Viala C, Dougados M, Gossec L. Efficacy and safety of steroid injections for shoulder and elbow tendonitis: a meta-analysis of randomised controlled trials. Ann Rheum Dis. 2009; 68(12):1843-9.

3. Centeno LM, Moore ME. Preferred intraarticular corticosteroids and associated practice: a survey of members of the American College of Rheumatology. Arthritis Care Res. 1994; 7(3):151-5.

4. Lawrence RC, Felson DT, Helmick CG, Arnold LM, Choi H, Deyo RA, et al.; National Arthritis Data Workgroup. Estimates of the prevalence of arthritis and other rheumatic conditions in the United States. Part II. Arthritis Rheum. 2008; 58(1):26-35

5. Loeser RF. Age-related changes in the musculoskeletal system and the development of osteoarthritis. Clin Geriatr Med. 2010; 26(3):371-86.

6. Zhang Y, Jordan JM. Epidemiology of osteoarthritis. Clin Geriatr Med. 2010; 26(3):355-69.

7. Hajialilo M, Ghorbanihaghjo A, Valaee L, Kolahi S, Rashtchizadeh N, Amirkhiz $\mathrm{MB}$, et al. A double-blind randomized comparative study of triamcinolone hexacetonide and dexamethasone intra-articular injection for the treatment of knee joint arthritis in rheumatoid arthritis. Clin Rheumatol. 2016; 35(12):2887-91.

8. Kumar A, Dhir V, Sharma S, Sharma A, Singh S. Efficacy of methylprednisolone acetate versus triamcinolone acetonide intra-articular knee injection in patients with chronic inflammatory arthritis: a 24-week randomized controlled trial. Clin Ther. 2017; 39(1):150-8.
9. Bird HA, Ring EF, Bacon PA. A thermographic and clinical comparison of three intra-articular steroid preparations in rheumatoid arthritis. Ann Rheum Dis. 1979; 38(1):36-9.

10. Lomonte AB, de Morais MG, de Carvalho LO, Zerbini CA. Efficacy of triamcinolone hexacetonide versus methylprednisolone acetate intraarticular injections in knee osteoarthritis: a randomized, double-blinded, 24-week study. J Rheumatol. 2015; 42(9):1677-84

11. Yavuz U, Sökücü S, Albayrak A, Oztürk K. Efficacy comparisons of the intraarticular steroidal agents in the patients with knee osteoarthritis. Rheumatol Int. 2012; 32(11):3391-6.

12. Pyne D, Ioannou Y, Mootoo R, Bhanji A. Intra-articular steroids in knee osteoarthritis: a comparative study of triamcinolone hexacetonide and methylprednisolone acetate. Clin Rheumatol. 2004; 23(2):116-20.

13. Oxford Centre for Evidence-based Medicine - Levels of Evidence. Available from: http://www.cebm.net/oxford-centre-evidence-based-medicine-levelsevidence-march-2009/.

14. Guyatt G, Gutterman D, Baumann MH, Addrizzo-Harris D, Hylek EM, Phillips B, et al. Grading strength of recommendations and quality of evidence in clinical guidelines: report from an American college of chest physicians task force. Chest. 2006; 129(1):174-81.

\section{AnNex I}

\section{Structured question}

- $\mathbf{P}$ - Adult patients with inflammatory arthritis or knee osteoarthritis.

- I - Single infiltration with methylprednisolone acetate injection.

- C - Triamcinolone acetonide or triamcinolone hexacetonide.

- $\mathbf{O}$ - Pain, function and adverse events.

\section{Search strategy}

Searches performed until June 18, 2017.

\section{PubMed-Medline}

- \#1: (Methylprednisolone AND Triamcinolone) AND Injections, Intra-Articular $=54$ studies retrieved.

- \#2: (Methylprednisolone OR Triamcinolone OR Glucocorticoid) AND Injections, Intra-Articular AND (Shoulder Joint OR Shoulder OR Knee Joint OR Knee) $=637$ studies retrieved.

- \#3: 1 OR $2=669$ studies retrieved.

- \#4: (1 OR 2) AND Random* $=228$ studies retrieved.

Central (Cochrane), Lilacs (via BVS)

- 'Methylprednisolone AND Triamcinolone'.

\section{Manual search}

- Reference within references, systematic reviews.

\section{Articles retrieved}

Obtaining evidence to be used for efficacy and harm analysis using methylprednisolone acetate, triamcinolone acetonide and triamcinolone hexacetonide in the treat- 
ment of inflammatory arthritis and knee osteoarthritis included the following steps: clinical question elaboration, question structuring, search for evidence, critical evaluation, and selection of evidence.

Initially selected by the title, then by the abstract, and finally by its full text, the latter being subject to critical evaluation and extraction of results related to the outcomes.

Medline

- Selected based on title: 20.

- Selected based on abstract: 6 .

- Selected after full text reading and critical assessment: 5 .

Central (Cochrane)

- One study selected (excluded for lack of full text).

Lilacs (via BVS)

- Selected: 0.

Manual search - Reference within references, revisions and guidelines

- Selected: 0 .

\section{Exclusion criteria for selected studies}

The strength of the evidence from experimental studies was defined taking into account the study design and corresponding bias risks, the results of the analysis (magnitude and precision), relevance and applicability (Oxford/ GRADE)..$^{13,14}$

\section{Language}

Articles in languages other than Portuguese, English or Spanish.

\section{According to publication}

Only full-text studies were considered for critical assessment.

\section{Data extraction}

The results obtained from the included studies were related to means and standard deviations of the scores (pain, function), and to the number of patients who presented recurrence (flare) with IA therapy, comparing methylprednisolone acetate with triamcinolone acetonide or triamcinolone hexacetonide, in the treatment of inflammatory arthritis and osteoarthritis of the knee. When expressed graphically, whenever possible, the results were estimated from their respective figures.

In Annex I, Tables 1 to 15, the characteristics of the study, including results and bias, are described.

\section{Critical evaluation and strength of evidence}

The recommendations were elaborated based on the authors' discussion about the selected literature, following the Oxford Grades of Recommendation. ${ }^{13}$

\section{Data analysis and expression}

We were not able to group studies, but the outcomes used the same measures to express their individual results. All results are available in the attached tables.

\section{TABLE 1 Descriptive table of study characteristics.}

\begin{tabular}{|c|c|c|c|c|c|}
\hline Study & Population (N) & Intervention (N) & Comparison (N) & Outcome & Follow-up time \\
\hline \multirow[t]{16}{*}{ Kumar et al. ${ }^{8}$} & A total of 170 patients & $\mathrm{N}=50$ & $\mathrm{~N}=50$ & The primary outcome was & 4,12 and 24 \\
\hline & (18 to 65 years) with & Intra-articular injection & Intra-articular & time to relapse at 24 weeks & weeks or whenever \\
\hline & rheumatoid arthritis & of $\mathrm{MA}(80 \mathrm{mg}, 2 \mathrm{~mL})$ at & injection of TA & & relapse was \\
\hline & $(n=89)$ or & the knee joint & $(80 \mathrm{mg}, 2 \mathrm{~mL})$ at & Secondary outcomes & suspected \\
\hline & spondyloarthrosis & & the knee joint & included changes in pain & \\
\hline & $(\mathrm{n}=11)$ and a severely & No local anesthetic was & & reported by the patient & \\
\hline & swollen knee joint & injected into the skin or & & and swelling at 4, 12 and & \\
\hline & (defined as duration $\geq 1$ & mixed with steroids & & 24 weeks; range of motion & \\
\hline & weeks and < 24 weeks) & & & (normal, mild, moderate & \\
\hline & were included & Additional use of & & or severely restricted) at 24 & \\
\hline & & intramuscular or IA (other & & weeks and adverse events & \\
\hline & Patients who received & joint) corticosteroid, or & & Patients rated pain and & \\
\hline & steroid infiltration in the & step-up therapy with oral & & swelling at the target joint & \\
\hline & same joint in the last 3 & steroids (prednisolone & & using a numerical rating & \\
\hline & months were excluded & $\geq 7.5 \mathrm{mg} /$ day) was not & & scale (NRS) ranging from & \\
\hline & & allowed for 4 weeks & & 0 to 10 & \\
\hline
\end{tabular}

MA: methylprednisolone acetate; TA: triamcinolone acetonide; NRS: numerical rating scale. 


\begin{tabular}{|c|c|c|c|c|c|c|c|}
\hline $\begin{array}{l}\text { Question } \\
\text { focal? }\end{array}$ & $\begin{array}{l}\text { Proper } \\
\text { randomization? }\end{array}$ & $\begin{array}{l}\text { Blinded } \\
\text { allocation? }\end{array}$ & Blinding? & $\begin{array}{l}\text { Losses } \\
\text { described? } \\
<20 \% \text { ? }\end{array}$ & $\begin{array}{l}\text { Prognostic } \\
\text { characteristics similar } \\
\text { between groups? }\end{array}$ & $\begin{array}{l}\text { Appropriate outcomes? } \\
\text { Appropriately } \\
\text { measured? Timely? }\end{array}$ & $\begin{array}{l}\text { ITT } \\
\text { analysis }\end{array}$ \\
\hline Yes & Yes & Yes & $\begin{array}{l}\text { Patient } \\
\text { blinding }\end{array}$ & $\begin{array}{l}\text { Described } \\
\text { and }<20 \%\end{array}$ & Yes & Yes & Yes \\
\hline
\end{tabular}

ITT: intention-to-treat analysis.

Sample calculation: present.

\section{TABLE 3 Outcomes and results of Kumar et al.}

\begin{tabular}{|c|c|c|}
\hline Study & Outcome & Results \\
\hline Kumar et al. ${ }^{8}$ & Primary outcome: & Nine patients relapsed in each group over 24 weeks (ARR=0\%, $95 \mathrm{Cl} 0.15-0.15$ \\
\hline \multirow{14}{*}{$\begin{array}{l}\text { Rheumatoid arthritis } \\
\text { and spondyloarthritis }\end{array}$} & time to relapse in 24 weeks & $\mathrm{NNH}=\mathrm{NS}$ ). The mean time to relapse was not significantly different between the MA \\
\hline & & and TA groups (20.8 [95Cl 18.8-22.7] weeks and $20.9[95 \mathrm{Cl} 19.0-22.8]$ weeks, \\
\hline & Secondary outcomes $(4,12$ & respectively: $\mathrm{p}=0.9$, hazard ratio $=1.0[95 \mathrm{Cl} 0.4-2.5])$ \\
\hline & and 24 weeks): & \\
\hline & & In both groups, there was a significant reduction in pain and swelling at all visits \\
\hline & Change reported by the & compared to the baseline visit $(p=0.001)$. However, there were no significant \\
\hline & patient (NRS) & intergroup (MA vs. TA) differences (4, 12 and 24 weeks). \\
\hline & - pain & In the ITT analysis, at 24 weeks, the results for pain and swelling (MA vs. TA) were 2.5 \\
\hline & - swelling & (2.3) vs. $3.4(3.1), p=0.33$, and $2.4(2.8)$ vs. $2.9(3.0), p=0.16$, respectively \\
\hline & Range of movement in 24 & There were no significant intergroup differences in range of motion within 24 weeks. \\
\hline & weeks & The normal flexion of the knee joint was present in 28 and 25 patients $(p=0.17)$ at \\
\hline & & baseline, and in 38 and 37 patients at 24 weeks (NNT=NS) \\
\hline & Adverse events & \\
\hline & & None of the patients had infection, hematoma or hypopigmentation \\
\hline
\end{tabular}

\section{TABLE 4 Descriptive table of study characteristics.}

\begin{tabular}{|c|c|c|c|c|c|}
\hline Study & Population (N) & Intervention $(\mathrm{N})$ & Comparison $(\mathrm{N})$ & Outcome & Follow-up time \\
\hline Bird et al. ${ }^{9}$ & $\begin{array}{l}\text { Thirty patients in an } \\
\text { outpatient or inpatient } \\
\text { setting presenting classic or } \\
\text { defined (ARA criteria) } \\
\text { rheumatoid arthritis, with } \\
\text { both knees symmetrically } \\
\text { affected by the disease } \\
\text { Patients who received } \\
\text { intra-articular or systemic } \\
\text { steroids in the previous } 3 \\
\text { months were excluded } \\
\text { Drug therapy remained } \\
\text { constant throughout } \\
\text { the study }\end{array}$ & $\begin{array}{l}\mathrm{N}=10 \\
\text { Single injection in one } \\
\text { knee with } \mathrm{MA} \text { ( } 40 \mathrm{mg} \\
\text { in } 1 \mathrm{~mL} \text { ) }\end{array}$ & $\begin{array}{l}\mathrm{N}=10 \\
\text { Single injection in one } \\
\text { knee with } \\
\mathrm{TH}(20 \mathrm{mg} \text { in } 1 \mathrm{~mL}) \\
\mathrm{N}=10 \\
\text { prednisolone t-butyl } \\
\text { acetate ( } 20 \mathrm{mg} \text { in } 1 \mathrm{~mL}) \\
\text { (comparison not included } \\
\text { in this review) }\end{array}$ & $\begin{array}{l}\text { Duration of morning } \\
\text { stiffness } \\
\text { Grip strength } \\
\text { Ritchie articular index } \\
\text { Thermographic index }\end{array}$ & 6 weeks \\
\hline
\end{tabular}

ARA: American Rheumatism Association; MA: methylprednisolone acetate; TH: triamcinolone hexacetonide; VAS: visual analogue scale. 


\begin{tabular}{|c|c|c|c|c|c|c|c|}
\hline $\begin{array}{l}\text { Question } \\
\text { focal? }\end{array}$ & $\begin{array}{l}\text { Proper } \\
\text { randomization? }\end{array}$ & $\begin{array}{l}\text { Blinded } \\
\text { allocation? }\end{array}$ & Blinding? & $\begin{array}{l}\text { Losses } \\
\text { described? } \\
<20 \% ?\end{array}$ & $\begin{array}{l}\text { Prognostic } \\
\text { characteristics } \\
\text { similar between } \\
\text { groups? }\end{array}$ & $\begin{array}{l}\text { Appropriate } \\
\text { outcomes? } \\
\text { Appropriately } \\
\text { measured? Timely? }\end{array}$ & $\begin{array}{l}\text { ITT } \\
\text { analysis }\end{array}$ \\
\hline Yes & Not described & $\begin{array}{l}\text { Not } \\
\text { described }\end{array}$ & $\begin{array}{l}\text { Double blinded } \\
\text { Not described }\end{array}$ & $\begin{array}{l}\text { Does not } \\
\text { describe } \\
\text { losses }\end{array}$ & Yes & $\begin{array}{l}\text { Outcomes are } \\
\text { appropriate; however, } \\
\text { values for pain (VAS) } \\
\text { and range of motion } \\
\text { (ROM) were not } \\
\text { reported }\end{array}$ & $\begin{array}{l}\text { No } \\
\text { reference }\end{array}$ \\
\hline
\end{tabular}

ITT: intention-to-treat analysis.

Sample calculation: present.

TABLE 6 Outcomes and results of Bird et al.

\begin{tabular}{|c|c|c|}
\hline Study & Outcome & Results \\
\hline Bird et al. ${ }^{9}$ & $\begin{array}{l}\text { Follow-up } 6 \text { weeks } \\
\text { - Pain on VAS }\end{array}$ & Improvement of pain: TH > MA at 1 week $(p<0.05)$, difference not maintained at 2 weeks $(p>0.1)$ \\
\hline $\begin{array}{l}\text { Rheumatoid } \\
\text { arthritis }\end{array}$ & $\begin{array}{l}\text { - Duration of morning stiffness } \\
\text { - Grip strength } \\
\text { - Ritchie articular index }\end{array}$ & $\begin{array}{l}\text { Compared with the baseline } \\
\text { - Morning stiffness did not show significant improvement in any group, } \mathrm{p}>0.5 \\
\text { - Grip strength did not show significant changes in any group, } \mathrm{p}>0.5 \\
\text { - Joint index did not show significant improvement in any group, } \mathrm{p}>0.5 \\
\text { The differences between MA and TH groups were not significant for these outcomes (duration } \\
\text { of morning stiffness, grip strength, Ritchie's Articular index) at any follow-up, up to } 6 \text { weeks }\end{array}$ \\
\hline
\end{tabular}

MA: methylprednisolone acetate; TH: triamcinolone hexacetonide; VAS: visual analogue scale.

TABLE 7 Descriptive table of study characteristics.

\begin{tabular}{|c|c|c|c|c|c|}
\hline Study & Population (N) & $\begin{array}{l}\text { Intervention } \\
(\mathrm{N})\end{array}$ & $\begin{array}{l}\text { Comparison } \\
\text { (N) }\end{array}$ & Outcome & $\begin{array}{l}\text { Follow- } \\
\text {-up time }\end{array}$ \\
\hline $\begin{array}{l}\text { Lomonte } \\
\text { et al. }{ }^{10}\end{array}$ & $\begin{array}{l}100 \text { patients analyzed according } \\
\text { to ITT } \\
\text { Patients with knee OA, } \\
\text { Kellgren-Lawrence grade II and } \\
\text { III radiologic classification, knee } \\
\text { pain on VAS } \\
\geq 40 \mathrm{~mm} \text { (maximum } 100 \mathrm{~mm} \text { ), } \\
\text { age } \geq 40 \text { years and failure to } \\
\text { control symptoms with previous } \\
\text { or current analgesics and/or } \\
\text { NSAIDs } \\
\text { The following were excluded: } \\
\text { patients with severe disease; } \\
\text { infiltration of corticosteroid or } \\
\text { hyaluronic acid in the previous } 6 \\
\text { months; use of anticoagulants }\end{array}$ & $\begin{array}{l}\mathrm{N}=50 \\
\text { Single intra-articular } \\
\text { injection of MA } 40 \\
\mathrm{mg} \text { in the most } \\
\text { symptomatic knee } \\
\text { No new } \\
\text { pharmacological or } \\
\text { non-pharmacological } \\
\text { therapy for knee OA } \\
\text { was allowed during } \\
\text { the study }\end{array}$ & $\begin{array}{l}\mathrm{N}=50 \\
\text { Single } \\
\text { intra-articular } \\
\text { injection of } \\
\mathrm{TH} 40 \mathrm{mg} \text { in } \\
\text { the most } \\
\text { symptomatic } \\
\text { knee }\end{array}$ & $\begin{array}{l}\text { Primary outcome: Patient pain assessment } \\
\text { on VAS (0-100 mm) at week } 4 \\
\text { Secondary outcomes: } \\
\text { - Patient pain assessment at weeks } 12 \text { and } 24 \text {. } \\
\text { - Global disease assessment performed by } \\
\text { the patient (VAS) at weeks } 4,12 \text { and } 24 \text {. } \\
\text { - Global disease assessment performed by } \\
\text { the physician (VAS) at weeks } 4,12 \text { and } 24 \text {. } \\
\text { - Global disease assessment performed by the } \\
\text { patient (Likert scale) at weeks } 4,12 \text { and } 24 \text {. } \\
\text { - OA WOMAC (pain, function and } \\
\text { activityrelated stiffness) questionnaire at } \\
4,12 \text { and } 24 \text { weeks } \\
\text { - Lequesne algofunctional index at weeks } \\
4,12 \text { and } 24 \\
\text { - OMERACT-OARSI criteria at weeks } 4,12 \\
\text { and } 24 \\
\text { - Adverse events }\end{array}$ & $\begin{array}{l}\text { Assessment } \\
\text { at weeks 4, } \\
12 \text { and } 24\end{array}$ \\
\hline
\end{tabular}

OA: osteoarthritis; MA: methylprednisolone acetate; TH: triamcinolone hexacetonide; NSAIDs: non-steroidal anti-inflammatory drugs; VAS: visual analogue scale; WOMAC: Western Ontario and McMaster Universities; OMERACT-OARSI: Outcome Measures in Rheumatology Clinical Trials and Osteoarthritis Research Society International. 


\begin{tabular}{|c|c|c|c|c|c|c|c|}
\hline $\begin{array}{l}\text { Question } \\
\text { focal? }\end{array}$ & $\begin{array}{l}\text { Proper } \\
\text { randomization? }\end{array}$ & $\begin{array}{l}\text { Blinded } \\
\text { allocation? }\end{array}$ & Blinding? & $\begin{array}{l}\text { Losses } \\
\text { described? } \\
<20 \% \text { ? }\end{array}$ & $\begin{array}{l}\text { Prognostic } \\
\text { characteristics } \\
\text { similar between } \\
\text { groups? }\end{array}$ & $\begin{array}{l}\text { Appropriate } \\
\text { outcomes? } \\
\text { Appropriately } \\
\text { measured? Timely? }\end{array}$ & $\begin{array}{l}\text { ITT } \\
\text { analysis }\end{array}$ \\
\hline Yes & Yes & Yes & $\begin{array}{l}\text { Triple-blinded } \\
\text { (patient, intervention } \\
\text { and evaluator) }\end{array}$ & $\begin{array}{l}\text { Yes and }<20 \% \\
(\text { loss }=10 \%)\end{array}$ & Yes & Yes & Yes \\
\hline
\end{tabular}

ITT: intention-to-treat analysis.

Sample calculation: present.

\section{TABLE 9 Outcomes and results of Lomonte et al.}

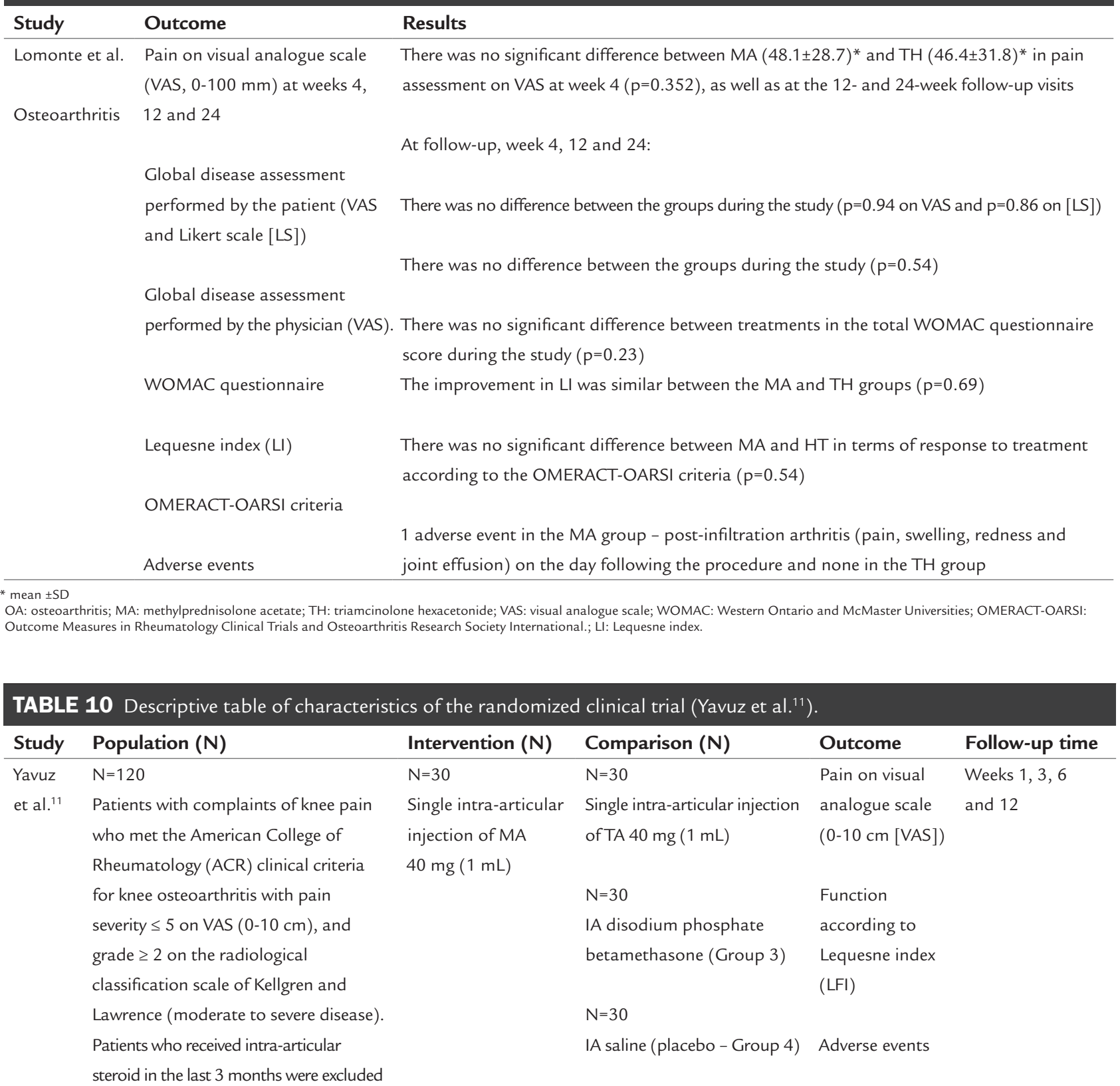

IA: intra-articular; LFI: Lequesne Functional Index. 


\section{TABLE 11 Descriptive table of biases in the randomized clinical trial (Yavuz et al. ${ }^{11}$ ).}

\begin{tabular}{|c|c|c|c|c|c|c|c|}
\hline $\begin{array}{l}\text { Question } \\
\text { focal? }\end{array}$ & $\begin{array}{l}\text { Proper } \\
\text { randomization? }\end{array}$ & $\begin{array}{l}\text { Blinded } \\
\text { allocation? }\end{array}$ & Blinding? & $\begin{array}{l}\text { Losses } \\
\text { described? } \\
<20 \% \text { ? }\end{array}$ & $\begin{array}{l}\text { Prognostic } \\
\text { characteristics } \\
\text { similar between } \\
\text { groups? }\end{array}$ & $\begin{array}{l}\text { Appropriate } \\
\text { outcomes? } \\
\text { Appropriately } \\
\text { measured? Timely? }\end{array}$ & $\begin{array}{l}\text { ITT } \\
\text { analysis }\end{array}$ \\
\hline Yes & $\begin{array}{l}\text { Strategy was not } \\
\text { reported }\end{array}$ & Not described & $\begin{array}{l}\text { Strategy was } \\
\text { not reported }\end{array}$ & Not described & Yes & Yes & $\begin{array}{l}\text { Not } \\
\text { reported }\end{array}$ \\
\hline
\end{tabular}

ITT: intention-to-treat analysis.

Sample calculation: absent.

\section{TABLE 12 Outcomes and results of Yavuz et al.}

\section{Study}

\section{Outcome}

\section{Results}

Yavuz et al. ${ }^{11} \quad$ Analyses at weeks 1, 3, 6 and 12
weeks; however, MA was more effective in relieving pain compared with the other agents (TA,

Osteoarthritis Pain on visual analogue scale ( 0 - betamethasone disodium phosphate and saline) until week 6; $p<0.05$ for all comparisons $10 \mathrm{~cm}[\mathrm{VAS}])$

There was no statistically significant difference between the MA and TA groups regarding Lequesne Functional Index (LI) improvement in functional status (LI) up to 12 weeks

Adverse events

MA: methylprednisolone acetate; TA: triamcinolone acetonide; VAS: visual analogue scale.

\section{TABLE 13 Descriptive table of study characteristics.}

\begin{tabular}{|c|c|c|c|c|c|}
\hline Study & Population (N) & Intervention (N) & Comparison (N) & Outcome & Follow-up time \\
\hline \multirow[t]{9}{*}{ Pyne et al. ${ }^{12}$} & Patients with knee $\mathrm{OA}$ and joint & $N=28$ & $N=29$ & Pain severity according & Weeks 0,3 and 8 \\
\hline & effusion, who met the ACR criteria & IA injection of MA & IA injection of & to VAS $(0-100 \mathrm{~mm})$ & \\
\hline & (clinical and radiographic) for knee OA & $40 \mathrm{mg}(1 \mathrm{~mL})$ & TH $20 \mathrm{mg}(1 \mathrm{~mL})$ & & \\
\hline & presenting at least grade II radiographic & & & Lequesne Functional & \\
\hline & OA changes according to the & & & Index (LI) & \\
\hline & Kellgren-Lawrence classification system. & & & & \\
\hline & Patients treated with infiltration in the & & & Time to ascend and & \\
\hline & last 3 months were excluded, as were & & & descend stairs using & \\
\hline & those with severe $\mathrm{OA}$ & & & handrails (TADS) & \\
\hline
\end{tabular}

ACR: American College of Rheumatology; MA: methylprednisolone acetate; TH: triamcinolone hexacetonide; VAS: visual analogue scale.

\begin{tabular}{|c|c|c|c|c|c|c|c|}
\hline $\begin{array}{l}\text { Question } \\
\text { focal? }\end{array}$ & $\begin{array}{l}\text { Proper } \\
\text { randomization? }\end{array}$ & $\begin{array}{l}\text { Blinded } \\
\text { allocation? }\end{array}$ & Blinding? & $\begin{array}{l}\text { Losses } \\
\text { described? } \\
<20 \% \text { ? }\end{array}$ & $\begin{array}{l}\text { Prognostic } \\
\text { characteristics } \\
\text { similar between } \\
\text { groups? }\end{array}$ & $\begin{array}{l}\text { Appropriate } \\
\text { outcomes? } \\
\text { Appropriately } \\
\text { measured? Timely? }\end{array}$ & $\begin{array}{l}\text { ITT } \\
\text { analysis }\end{array}$ \\
\hline Yes & $\begin{array}{l}\text { Strategy was not } \\
\text { reported }\end{array}$ & $\begin{array}{l}\text { Strategy was } \\
\text { not reported }\end{array}$ & $\begin{array}{l}\text { Double-blinded } \\
\text { (patient and } \\
\text { evaluator) }\end{array}$ & $\begin{array}{l}\text { Not } \\
\text { described }\end{array}$ & Yes & Yes & No \\
\hline
\end{tabular}

ITT: intention-to-treat analysis.

Sample calculation: present. 


\section{TABLE 15 Outcomes and results of Pyne at al.}

\begin{tabular}{ll} 
Study & Outcome \\
\hline Pyne et al. $^{12}$ & Follow-up 3 to 8 weeks \\
Osteoarthritis & Pain severity according to VAS $(0-100 \mathrm{~mm})$ \\
& - Lequesne Functional Index (LI) \\
& Time to ascend and descend stairs using \\
& handrails (TADS)
\end{tabular}

Results

$\mathrm{TH}$ was more effective than MA in reducing pain at week $3(32.9 \mathrm{~mm}$, $95 \mathrm{Cl} 23.4-42.4 \mathrm{~mm}$ vs. $13.7 \mathrm{~mm}, 95 \mathrm{Cl} 2.8-24.8 \mathrm{~mm}, \mathrm{p}<0.01)$; this difference was lost at week $8(p=0.17)$

There was no significant difference between the two drugs (MA vs. TH) in the assessment of function ( $\mathrm{LI}$ and TADS) at 3 and 8 weeks ( $>>0.05$ for all comparisons)

LI: Lequesne index.

\section{Description of evidence}

The available evidence will follow some principles to be displayed:

- by outcome;

- by study design (randomized clinical trial).

\section{Recommendation}

The global synthesis will be elaborated considering the described evidence and the strength (Oxford/GRADE) $)^{13,14}$ will be estimated as $1 \mathrm{~b}$ and $1 \mathrm{c}$ (grade $\mathrm{A}$ ) or strong, and $2 \mathrm{a}$, $2 \mathrm{~b}$ and $2 \mathrm{c}$ (grade $\mathrm{B}$ ) or moderate, weak or very weak. The strongest evidence will be considered. 